Vol. 1 No. 2 September 2021, p-2797-5592 | e-2797-5606

\title{
MENINGKATKAN KINERJA GURU PRODUK KREATIF DAN KEWIRAUSAHAAN MELALUI PROGRAM SEKOLAH PENCETAK WIRAUSAHA
}

\author{
FRANSISKA ANDAYANI \\ SMK Negeri 1 Tanjung Palas, Kab. Bulungan, Kalimantan Utara \\ Email : fransiskaandayani134@gmail.com
}

\begin{abstract}
ABSTRAK
Meningkatkan kinerja guru mata pelajaran produktif dan kewirausahaan melalui program sekolah pencetak wirausaha, adalah antara lain cara sekolah untuk menghasilkan lulusan yang memiliki jiwa kewirausahaan. Sekolah atau pendidikan menjadi tempat yang sangat strategis untuk menumbuhkan bakat wirausaha. Akan tetapi selain bakat, motivasi dan pengetahuan mengenai berwirausaha juga harus diberikan. Program sekolah pencetak wirausaha merupakan serangkaian kegiatan untuk membentuk dan membuka pola pikir siswa yang akan lulus untuk menggeluti dunia wirausaha, sehingga peserta didik tidak hanya berfikir untuk bekerja diindustri, tetapi sebagai pencipta lapangan kerja mandiri. Program ini membutuhkan lima komponen pendukung yaitu kepala sekolah sebagai penggerak, guru sebagai pembimbing, peserta didik sebagai pelaksana usaha, masyarakat sebagai pendukung dan konsumen, serta pemerintah sebagai fasilitator. Program sekolah pencetak wirausaha dilaksanakan pada Kompetensi Keahlian Agribisnis Tanaman Pangan dan Hortikultura, Agribisnis Perikanan Air Tawar dan Agribisnis Pengolahan Hasil Perikanan kelas XI, semester ganjil tahun ajaran 2020/2021.
\end{abstract}

Kata Kunci : Kinerja Guru, Sekolah Pencetak Wirausaha

\section{PENDAHULUAN}

Standar Nasional Pendidikan Sekolah Menengah Kejuruan menjelaskan mengenai profil lulusan SMK yaitu : (1) beriman, bertakwa, dan berbudi pekerti luhur; (2) memiliki sikap mental yang kuat untuk mengembangkan diri secara berkelanjutan; (3) menguasai ilmu pengetahuan, teknologi, dan seni serta memiliki keterampilan sesuai dengan kebutuhan pembangunan; (4) memiliki kemampuan produktif sesuai dengan bidang keahliannya baik untuk bekerja pada pihak lain maupun berwirausaha, dan (5) berkontribusi dalam pembangunan industry Indonesia yang kompetitif menghadapi pasar global. Proses pembelajaran diselenggarakan dengan berbasis aktivitas secara interaktif, inspiratif, menyenangkan, menantang, dan memotivasi peserta didik (Peraturan Menteri Pendidikan dan Kebudayaan Nomor 34, 2018).

SMK sebagai penyelenggara pendidikan, diharapkan menghasilkan lulusan yang relevan dengan kebutuhan IDUKA atau dapat berwirausaha. Untuk menghasilkan lulusan yang produktif sesuai dengan bidang keahliannya, kemudian memiliki kemampuan berwirausaha serta relevan dengan perubahan yang terjadi di dunia kerja atau masyarakat maka konsep pendidikan kejuruan hendaknya mampu mengadaptasi pola pengembangan pendidikan yang berbasis pengetahuan dan teknologi serta entrepreneur, yang merupakan salah satu solusi menghadapi tantangan global yang semakin kompetitif, serta pengembangan pendidikan kejuruan yang bersinergi dengan dengan pola pengembangan kewirausahaan juga merupakan antisipasi menghadapi tantangan perubahan yang semakin cepat (Said \& Rukin, 2019: 1).

SMK Negeri 1 Tanjung Palas sebagai penyelenggara pendidikan, bertujuan untuk menghasilkan lulusan yang relevan dengan kebutuhan IDUKA atau menjadi wirausaha. Kondisi lulusan SMK Negeri 1 Tanjung Palas saat ini, belum memenuhi stándar IDUKA, bekerja namun tidak sesuai dengan kompetensi keahliannya dan sedikit sekali yang menjadi wirausaha.

Untuk menghasilkan lulusan yang berstandar IDUKA atau menjadi wirausaha tidak terlepas dari peran guru. Menurut Wijaya dan Rusyan dalam (Darmadi, 2018) bahwa peran guru 
belum dapat diganti dan diambil alih oleh apapun, serta merupakan faktor yang sangat dominan dan paling penting dalam pendidikan formal.

Guru dituntut memiliki kinerja yang mampu memberikan dan merealisasikan harapan dan keinginan semua pihak terutama masyarakat umum yang telah mempercayai sekolah dan guru dalam membina anak didik (Darmadi, 2018). Sehingga SMK Negeri 1 Tanjung Palas berusaha meningkatkan kinerja guru yang mengampu mata pelajaran Produk Kreatif dan Kewirausahaan dalam membina peserta didik agar memiliki jiwa kewirausahaan, serta dapat memiliki produk sendiri. SMK Negeri 1 Tanjung Palas fokus pada pengembangan kewirausahaan bagi peserta didik, karena peluang kerja di IDUKA sangat terbatas, dan tidak sesuai dengan kompetensi keahlian yang ada di SMK Negeri 1 Tanjung Palas, hal ini berdampak pada rendahnya lulusan SMK Negeri 1 Tanjung Palas yang bekerja di IDUKA.

Menghadapi permasalahan diatas, pada bulan Desember 2020 sampai dengan sekarang, SMK Negeri 1 Tanjung Palas mengikuti program Sekolah Pencetak Wirausaha (SPW). Program Sekolah Pencetak Wirausaha adalah sinergi antara PSMK, SEAMEO, SEAMOLEC, dengan model pengembangan pembelajaran berdasarkan praktik usaha berbasis omset pemasaran. Program ini dilaksanakan dengan métode pendampingan secara terpadu dengan pola jarak jauh menggunakan TIK. Pembelajaran kewirausahaan merupakan suatu pembelajaran tentang etika, nilai (value), kemampuan (ability), dan perilaku (attitude) dalam menghadapi tantangan hidup untuk memperoleh peluang dengan berbagai resiko yang dihadapi. Pengembangan pembelajaran kewirausahaan melalui peminatan berbasis pengukuran omset dan monitoring berkelanjutan melalui program sekolah pencetak wirausaha (Direktorat Sekolah Menengah Kejuruan).

Selaras dengan hasil penelitian menunjukkan, pembelajaran kewirausahaan melalui sekolah pencetak wirausaha muda, signifikan dapat melahirkan wirausahawan (Deviany, 2020). Selanjutnya hasil penelitian dari Arfah dan Subali (2021) menunjukkan Sekolah Pencetak Wirausaha (SPW) memiliki pengaruh positif terhadap minat wirausaha siswa dan membantu siswa dalam menumbuhkembangkan minat wirausaha siswa yang dimilikinya.

Pelaksanaan program sekolah pencetak wirausaha dilaksanakan pada kompetensi keahlian Agribisnis Tanaman Pangan dan Hortikultura, Agribisnis Perikanan Air Tawar, dan Agribisnis Pengolahan Hasil Perikanan berpengaruh secara signifikan terhadap peningkatan kinerja guru SMK Negeri 1 Tanjung Palas, menjadi motivasi menuliskan Best Practice ini.

\section{METODE PELAKSANAAN}

Penulis memilih meningkatkan kinerja guru produk kreatif dan kewirausahaan melalui sekolah pencetak kewirausahaan untuk menghasilkan peserta didik yang memiliki jiwa kewirausahaan. Best practice ini akan menunjukkan dengan meningkatmya kinerja guru produk kreatif dan kewirausahaan memiliki dampak pada jiwa kewirausahaan peserta didik serta rencana aksi yang disusun oleh guru, dokumentasi kegiatan kewirausahaan yang dilaksanakan oleh guru dan peserta didik, jadwal pelaksanaan kegiatan dan omset peserta didik. Kesimpulan best paractice digambarkan dalam bentuk tabel dan gambar, agar mempermudah bagi penulis dan orang lain untuk memahami.

Best practice dilaksanakan pada Semester Ganjil Tahun Ajaran 2020/2021 mulai tanggal 23 Desember 2020 sampai dengan 25 Oktober 2021. Tempat pelaksanaan best practice di SMK Negeri 1 Tanjung Palas, Jalan M.Tayib, Kelurahan Tanjung Palas Hilir, Kecamatan Tanjung Palas Kabupaten Bulungan Provinsi Kalimantan Utara. Prosedur pelaksanaan disusun bersama antara guru produk kreatif dan kewirausahaan dengan diketahui oleh Kepala Sekolah, bahan yang digunakan adalah pembelajaran berbasis produk melalui program sekolah pencetak wirausaha, pada Kompetensi Keahlian Agribisnis Tanaman Pangan dan Hortikultura, Agribisnis Perikanan Air Tawar dan Agribisnis Pengolahan Hasil Perikanan, kelas XI. 


\section{HASIL DAN PEMBAHASAN}

\section{A. Hasil}

Berikut tahapan pelaksanaan best practise, untuk meningkatkan kinerja guru produk kreatif dan kewirausahaan melalui program sekolah pencetak wirausaha. Kegiatan yang dilakukan oleh Kepala Sekolah, guru dan peserta didik sebagai berikut: (1) Melakukan koordinasi antara kepala sekolah dengan guru mata pelajaran produktif kreatif dan kewirausahaan, dalam rangka menentukan tim guru pembina sekolah pencetak wirausaha, pada tahapan ini kepala sekolah dan guru menyamakan persepsi dan komitmen tentang program sekolah pencetak wirausaha; (2) Menetapkan guru pembimbing program sekolah pencetak wirausaha, sekolah perlu untuk mengeluarkan surat keputusan kepala sekolah tentang pembentukan tim sekolah pencetak wirausaha; (3) Menetapkan peserta didik yang mengikuti program sekolah pencetak wirausaha, hal ini dilakukan agar pembinaan peserta didik menjadi lebih baik; (3) Guru melaksanakan pembimbingan kepada peserta. Peserta didik yang mengikuti program sekolah pencetak wirausaha dapat dibedakan menjadi, peserta didik yang memiliki usaha, peserta didik yang memiliki produk dan peserta didik yang tidak memiliki usaha juga tidak memiliki produk. Pembimbingan dilakukan pada, promosi produk, pembuatan produk, pencatatan omset perbulan, mengidentifikasi masalah dan pemecahan masalah yang dihadapi oleh peserta didik ketika melaksanakan kegiatan kewirausahaan; (4) Guru dan peserta didik yang mengikuti pelatihan Virtual Coordinating Training (VCT). Guru dan peserta didik dilatih untuk bisa menjadi host, moderator dan presentasi secara virtual, selain itu guru dan peserta didik diajari membuat flyer, yang berguna untuk melakukan promosi produk. (5) Guru melakukan análisis produk, hal ini dilakukan untuk membuat produk unggulan sekolah yang dapat dibuat oleh seluruh peserta didik. Produk yang ditetapkan untuk dibuat oleh seluruh peserta didik adalah aneka sambal dan "BATARI" yaitu Bandeng tanpa duri original dan bandeng tanpa duri bumbu; (6) Membimbing peserta didik dalam promosi produk sekolah. Produk sekolah yang telah dibuat, harus dilakukan promosi agar dapat diketahui dan diterima oleh masyarakat selaku konsumen; (7) Mengikuti Kamp Kreatif Guru SMK Indonesia SPW tahun 2021. Kegiatan ini bertujuan agar guru dapat melatih, memotivasi dan membimbing siswa untuk berwirausaha sehingga mencapai omset yang ingin dicapai. Kegiatan Kamp Kretaif Guru SMK Indonesia SPW tempat berkumpulnya guru pembimbing kewirausahaan dan guru mata pelajaran produk kreatif dan kewirausahaan SMK se Indonesia, disini guru dapat berbagi pengalaman dan informasi dalam rangka menjadikan peserta didik menjadi wirausaha. (8) Melakukan evaluasi omset peserta didik setiap akhir bulan. Pada program sekolah pencetak wirausaha, peserta didik diharuskan melakukan pencatatan terhadap omset peserta didik setiap bulannya. Hal ini dilakukan untuk mengetahui progress omset yang dihasilkan oleh peserta didik setiap bulannya. (9) Memfasilitasi peserta didik untuk melaporkan hasil kegiatan kewirausahaannya. Peserta didik akan melaporkan hasil kegiatannya selama melakukan kegiatan kewirausahaan, seperti: omset yang dicapai, permasalahan yang dihadapi dan bagaimana pemecahan masalah yang dilakukan oleh peserta didik. Dalam proses penyusunan laporan ini, peserta didik dibimbing oleh guru agar laporan dapat menggambarkan progres peserta didik selama mengikuti program sekolah pencetak wirausaha.

Peserta didik yang mengikuti program sekolah pencetak wirausaha, diharuskan untuk mencatat omset yang diperoleh setiap bulan. Omset peserta didik yang mengikuti program sekolah pencetak wirausaha, ditunjukkan pada tabel 1, dibawah ini:

Tabel 1. Omset Peserta Sekolah Pencetak Wirausaha

\begin{tabular}{cccc}
\hline No & Bulan & Tahun & Omset \\
\hline 1 & Desember & 2020 & Rp 17.624.000 \\
2 & Januari & 2021 & Rp 15.179.000 \\
3 & Pebruari & 2021 & Rp 11.256.000 \\
4 & Maret & 2021 & Rp 14.975.000 \\
5 & April & 2021 & Rp 38.500.000 \\
\hline
\end{tabular}


MANAJERIAL : Jurnal Inovasi Manajemen dan Supervisi Pendidikan

Vol. 1 No. 2 September 2021, p-2797-5592 | e-2797-5606

\begin{tabular}{cccc}
\hline 6 & Mei & 2021 & Rp 9.555 .000 \\
7 & Juni & 2021 & $\operatorname{Rp~} 350.000$ \\
8 & Juli & 2021 & Rp 0 \\
9 & Agustus & 2021 & Rp 3.365.000 \\
10 & September & 2021 & Rp 3.685 .000 \\
\hline
\end{tabular}

Dari Tabel 2, omset peserta didik dapat ditunjukkan seperti pada Grafik 1, di bawah ini:

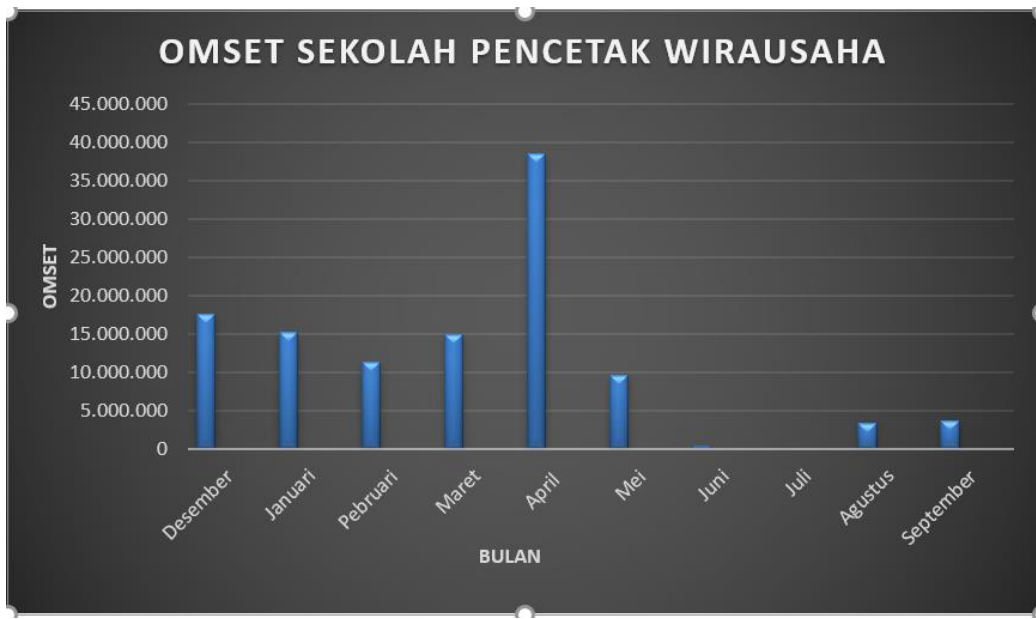

Gambar 1. Grafik Omset Sekolah Pencetak Wirausaha

Gambar 2 dan gambar 3 adalah kegiatan peserta didik yang mengikuti program sekolah pencetak wirausaha, ketika membuat produk aneka sambal dan bandeng tanpa duri. Pemilihan produk yang akan dibuat telah melalui análisis peluang produk diterima di pasar atau di masyarakat. Analisis produk dilakukan oleh musyawarah guru mata pelajaran produk kreatif dan kewirausahaan, kemudian di sosialisasikan kepada peserta didik program sekolah pencetak wirausaha.
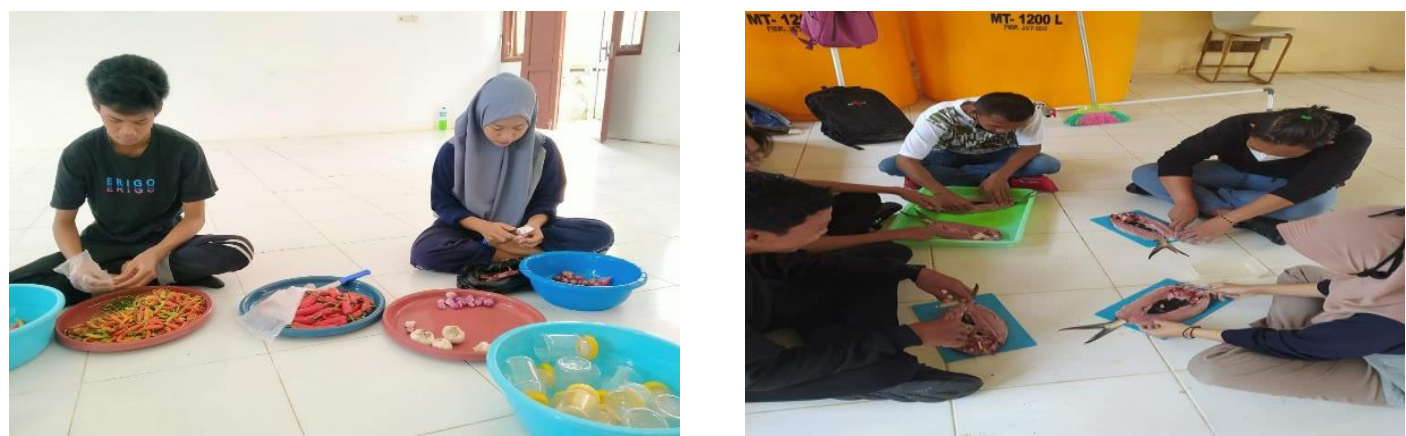

Gambar 2. Gambar 3.
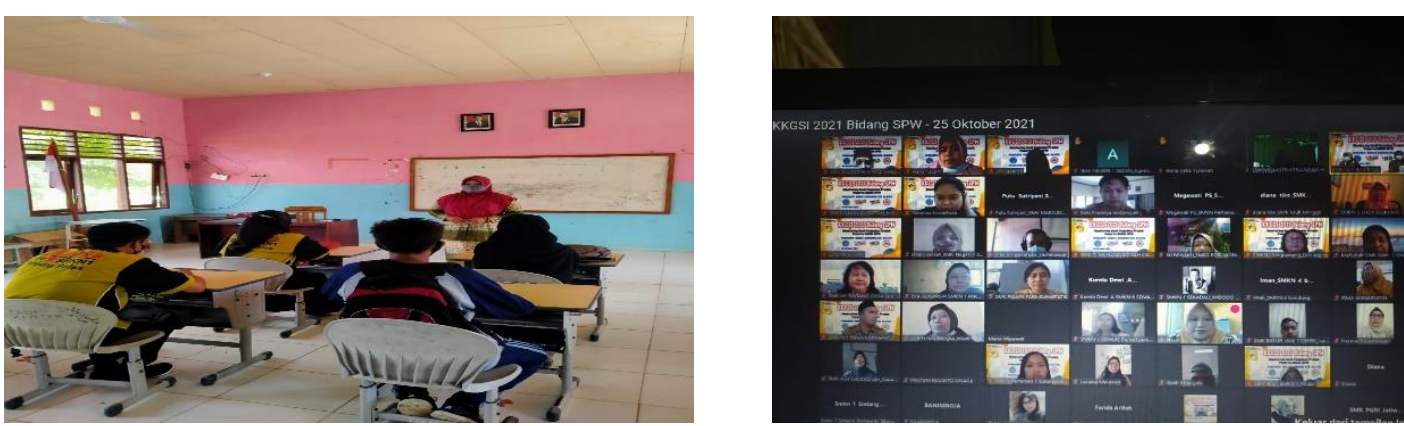

Gambar 4. Gambar 5. 
Selanjutnya Gambar 4, menunjukkan peran guru dalam melakukan pembinaan kepada peserta didik program sekolah pencetak wirausaha. Pembinaan dilakukan setelah melakukan evaluasi omset yang dihasilkan peserta didik. Progress ataupun turunnya omset, menjadi bahan diskusi atau pembinaan dan penguatan dari guru.

Kemudian Gambar 5, merupakan bentuk usaha guru mata pelajaran produk kreatif dan kewirausahaan dalam mengembangkan soft skill dan keterampilan guru melalui pelatihan kamp kreatif guru SMK Indonesia- SPW tahun 2021. Kegiatan ini membantu guru dalam penguatan melakukan pembinaan dan mengembangakan potensi wirausaha peserta didik agar dapat mencapai omset yang diinginkan.
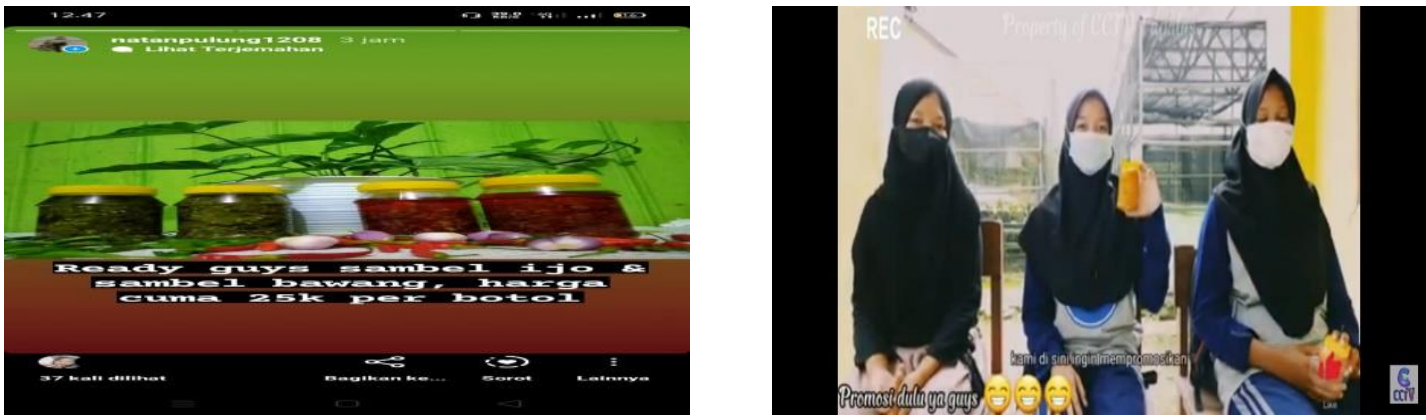

Gambar 6. Gambar 7.

Dalam kegiatan kewirausahaan, selain produk yang berkualitas, promosi produk merupakan bagian terpenting dalam meningkatkan hasil penjualan produk atau omset. Gambar 6 dan 7, merupakan kegiatan promosi peserta didik yang tergabung dalam program sekolah pencetak wirausaha. Kegiatan promosi yang dilakukan peserta didik tidak terlepas dari binaan dan pantauan guru yang merupakan tim program sekolah pencetak wirausaha. Promosi dilakukan menggunakan media social peserta didik masing-masing, baik Whatsapp, Facebook, Instagram serta Youtube.

Peserta didik yang mengikuti program sekolah pencetak wirausaha, terdiri dari peserta didik yang telah memiliki usaha seperti online shop dan reseller, selain itu terdapat peserta didik yang memang telah memiliki produk sendiri seperti berjualan Donut aneka toping, sembako, nasi goreng dan bubur ayam, ada juga peserta didik yang memiliki semangat untuk berwirausaha namun belum memiliki usaha ataupun produk.

\section{B. Pembahasan}

Menghasilkan lulusan SMK yang mampu diserap oleh dunia kerja dan dunia industri, kemudian mampu menjadi wirausaha adalah antara lain yang ingin dicapai oleh SMK Negeri 1 Tanjung Palas sebagai penyelenggara pendidikan vokasi. Untuk dapat diserap oleh industri sepenuhnya sangat tergantung pada peluang kerja atau rekrutmen yang dilakukan oleh industri, artinya walaupun lulusan SMK memiliki skill keterampilan yang relevan jika tidak adanya peluang kerja dari industri maka lulusan tidak akan dapat bekerja. Antisipasi keadaan diatas maka SMK Negeri 1 Tanjung Palas meningkatkan kemampuan wirausaha peserta didik. Kewirausahaan memainkan peran yang berpengaruh dalam pertumbuhan ekonomi dan stándar kehidupan negara, dan wirausaha berperan sebagai : (a) pencipta kekayaan dan bebrbagi; (b) penghasil atau pencipta lapangan pekerjaan; (c) pembangun ekonomi regional yang seimbang; (d) penopang peningkatan estándar kehidupan masyarakat;(e) pelaku ekspor untuk memperluas bisnis ke pasar luar negeri; (f) penopang peningkatan PDB dan per kapita; (g) pencipta bisnis baru sebagai tanggapan terhadap kebutuhan dan permintaan yang tidak terpenuhi di pasar seperti produk layanan (Marsono, Sulistyani \& Lathifah, 2020).

Sekolah atau pendidikan menjadi tempat yang sangat strategis untuk menumbuhkan bakat wirausaha. Akan tetapi selain bakat, motivasi dan pengetahuan mengenai berwirausaha juga harus diberikan (Prihastiwi, Army, \& Fatimah, 2018). Menjadikan peserta didik memiliki 
jiwa kewirausahaan diperlukan perencanaan dan komitmen seluruh warga sekolah dalam melaksanakannya, hal ini tidak terlepas dari peran guru yang akan memberikan pembinaan, penguatan dan membuka wawasan bagi peserta didik dalam berwirausaha. Tantangan yang dihadapi bagi pengajar kewirausahaan adalah menggali potensi peserta didik dan lingkungan sekitar untuk bisa membuka wawasan cakrawala dan keterampilan peserta didik dalam menghasilkan produk yang bernilai jual selama mereka menempuh pendidikan di SMK (Basri, Faiza, Nasir \& Nasrun, 2019).

Untuk meningkatkan kinerja guru mata pelajaran produk kreatif dan kewirausahaan, maka sekolah perlu menciptakan kondisi agar guru dapat memberikan pembelajaran berbasis produk melalui program sekolah pencetak wirausaha. Pada program sekolah pencetak wirausaha, guru dituntut untuk melakukan pembinaan kepada peserta didik untuk melakukan pencatatan omset setiap bulan, kemudian guru dan peserta didik diberikan pelatihan tentang promosi produk atau usaha peserta didik, guru membina dan memfasilitasi peserta didik yang mengalami kesulitan dalam meningkatkan omsetnya. Program sekolah pencetak wirausaha, memberikan budaya dan iklim kerja yang kondusif akan memungkinkan guru lebih termotivasi untuk menunjukkan kinerjanya secara unggul, yang disertai usaha untuk meningkatkan kompetensinya (Susanto Ahmad, 2016).

Program sekolah pencetak wirausaha merupakan serangkaian kegiatan untuk membentuk dan membuka pola pikir siswa yang akan lulus untuk menggeluti dunia wirausaha, sehingga peserta didik tidak hanya berfikir untuk bekerja diindustri, tetapi sebagai pencipta lapangan kerja mandiri. Program ini membutuhkan lima komponen pendudkung yaitu kepala sekolah sebagai penggerak, guru sebagai pembimbing, peserta didik sebagai pelaksana usaha, masyarakat sebagai pendukung dan konsumen, serta pemerintah sebagai fasilitator. Sekolah pencetak wirausaha menghendaki peserta didik untuk menumbuhkan sikap wirausaha, seperti: (a) perilakunya terpuji, disiplin, jujur, tekun; (b) berani menanggung resiko dengan penuh perhitungan yang matang; (c) mempunyai daya kreasi, motivasi, dan imajinasi; (d) hidup efisien, tidak boros, tidak pamer kekayaan; (e) mampu menarik orang lain, karyawan untuk bekerja sama; (f) mampu menganalisis, melihat peluang (Barliana, 2019). Relevan dengan hasil penelitian, bahwa terdapat pengaruh positif antara variable program sekolah pencetak wirausaha dengan variable minat wirausaha pada uji regresi sederhana, artinya adanya program sekolah pencetak wirausaha dapat membantu siswa dalam menumbuhkembangkan minat wirausahanya (Arfah, H., \& Subali. 2021).

Guru menjadi komponen penting dalam pelaksanaan program sekolah pencetak wirausaha, sebagai pembimbing, fasilitator dan motivator bagi peserta didik. Peserta didik dituntut untuk memiliki omset selama mengikuti program sekolah pencetak wirausaha, jika didalam prosesnya peserta didik mengalami kesulitan atau hambatan, maka guru mengambil peran sebagai pembimbing untuk memberikan arahan, penguatan dan cara menemukan solusi bagi permasalahan yang dihadapi oleh peserta didik. Dalam program sekolah pencetak wirausaha ini, guru membantu siswa agar siswa dapat mencapai target, omset yang diinginkan. Untuk dapat membantu siswa, maka guru perlu juga mendapatkan pelatihan peningkatan kompetensinya dibidang kewirausahaan, dalam hal ini guru mengikuti kegiatan kamp kreatif guru SMK Indonesia. Pada kegiatan ini guru dilatih, untuk dapat membantu peserta didik mencapai target omsetnya, dan melakukan kegiatan kewirausahaan yaitu proses kegiatan kreativitas dan inovasi menciptakan perubahan dengan memanfaatkan peluang dan sumbersumber yang ada untuk menghasilkan nilai taambah bagi diri sendiri dan orang lain serta memenangkan persaingan (Mardia et al., 2019).

Pelaksanaan program sekolah pencetak wirausaha di SMK Negeri 1 Tanjung Palas diikuti oleh peserta didik yang telah memiliki usaha online shop, kemudian peserta didik yang memiliki produk, serta peserta didik yang sama sekali belum memiliki usaha ataupun produk. Untuk peserta didik yang belum memiliki usaha ataupun produk, maka menjadi tugas guru mata pelajaran produk kreatif dan kewirausahaan untuk memfasilitasi peserta didik agar dapat melakukan kegiatan kewirausahaan, dengan cara melakukan analisis produk yang dapat 
diterima dimasyarakat. Analisis produk dilakukan oleh guru mata pelajaran produk kreatif dan kewirausahaan dan diketahui oleh Kepala Sekolah. Produk yang telah dianalisis kelayakannya, selanjutnya akan dikerjakan oleh peserta didik di bawah pengawasan dan bimbingan guru. Tidak hanya sampai pada pembuatan produk, guru juga membantu peserta didik dalam kegiatan promosi produk, sehingga produk yang dihasilkan oleh peserta didik menarik minat konsumen. Tahapan selanjutnya guru mengawasi pencatatn omset yang dilakukan oleh peserta didik, agar tidak terjadi kelalaian peserta didik dalam mencatat omset yang diperolehnya. Pencatatan omset sangat penting, untuk dijadikan bahan análisis bagi peserta didik dan guru. Kinerja guru mata pelajaran produk kreatif dan kewirausahaan yang tinggi melalui program sekolah pencetak wirausaha akan memiliki pengaruh posiitf bagi peserta didik dalam pengembangan jiwa kewirausahaannya.

\section{KESIMPULAN}

Kesimpulan yang dapat diambil dari best practise ini adalah : 1) Kinerja guru mata pelajaran produk kreatif dan kewirausaahn melalui program sekolah pencetak wirausaha layak dijadikan best practice, karena sekolah dapat mendorong dan memotivasi guru untuk meningkatkan kompetensi kewirausahaannya, menciptakan produk sekolah yang dapat digunakan oleh peserta didik untuk dapat menghasilkan omset. 2) Program sekolah pencetak wirausaha yang dilaksanakan dapat menghasilkan peserta didik yang memiliki jiwa kewirausahaan, yaitu: bertanggung jawab, disiplin, kerja keras, kreatif dan inovatif, jujur serta dapat membaca peluang usaha, guna menciptakan lapangan pekerjaan.3) Peningkatan kinerja guru mata pelajara produktif dan kewirausahaan melalui program sekolah pencetak wirausaha mampu mendorong terciptanya wirausaha-wirausaha muda dan lulusan SMK yang mandiri serta berdaya saing.

\section{DAFTAR PUSTAKA}

Arfah, H., \& Subali. (2021). Implementasi Program Sekolah Pencetak Wirausaha Terhadap Minat Berwirausaha Siswa SMKN 1 Cimahi. Jurnal Pendidikan Ekonomi. 15 (2).

Barliana Lutfah. (2019). Vistra Mewujudkan Sekolah Pencetak Wirausaha Negeri Atas Awan di SMK Negeri 1 Blado. Media Penelitian Pendidikan. 13 (2).

Basri, I,, Faiza, D., Nasir, M., \& Nasrun. (2019). Implementasi Pembelajaran Berbasis Produk Dalam Rangka Menyiapkan Lulusan SMK Menjadi Wirausaha Muda. Invotek: 19 (1).

Darmadi. (2018). Membangun Paradigma Baru Kinerja Guru.

Deviani. (2020). Pembelajaran Kewirausahaan Sebagai Pencetak Wirausahawan Muda Pada Siswa Jurusan Tata Boga Di SMK Muhammadiyah Belitung Timur.

Direktorat Sekolah Menengah Kejuruan. (2019). Pendaftaran Sekolah Pencetak Wirausaha Batch 4 - Tahun 2019.

Mardia, Hasibuan, A., Simarmata,J., Kuswanto, Litchatullaillah,E. (2019). Kewirausahaan.

Marsono, S.,Sulistyani,L., \& Lathifah, I., (2020). Pelatihan Kewirausahaan Dalam Mewujudkan Keamndirian Ekonomi Bagi Siswa Sekolah Menengah Kejuruan (SMK) PGRI Di Surakarta. Wasana Nyata: 4(2), p. 131-136,

Peraturan Menteri Pendidikan dan Kebudayaan Nomor 34. (2018). Standar Nasional Pendidikan Sekolah Menengah Kejuruan/Madrasah Aliyah Kejuruan

Prihastiwi, Army, \& Fatimah. (2018, 374-380). Optimalisasi Peran SMK Sebagai Pencetak Wirausahawan Muda Melalui Penguatan Motivasi Dan Pembekalan Keterampilan dan Pengetahuan Kewirausahaan.

Said \& Rukin, (2019). Inovasi Kebijakan Pendidikan Kejuruan Berbasis Entrepreneu.

Susanto Ahmad. (2016). Konsep, Strategi, Dan Implementasi Manajemen Peningkatan Kinerja Guru. 